\title{
PENERIMAAN RETRIBUSI PASAR KABUPATEN LEBONG (Studi Terhadap Jumlah Pedagang Dan Pertumbuhan Ekonomi)
}

\author{
ELLYA REVOLINA \\ YULIANI \\ Dosen Fakultas Ekonomi Universitas Prof. Dr. Hazairin, SH Bengkulu
}

\begin{abstract}
ABSTRAK
Ellya Revolina, Yuliani; Tujuan penelitian ini untuk mengetahui besarnya pengaruh jumlah pedagang kios, pedagang los dan pertumbuhan ekonomiterhadap penerimaan retribusi pasar di Kabupaten Lebongtahun 2004 - 2011. Data yang penulis gunakan adalah data sekunder dan metode pengambilan sampel dilakukan dengan metode purposive sampling yaitu jumlah pedagang kios, pedagang los dan pertumbuhan ekonomiterhadap penerimaan retribusi pasar di Kabupaten Lebongtahun 2004 - 2011. Berdasarkan hasil perhitungan diperoleh Koefisien Determinasi Berganda $\left(\mathrm{R}^{2}\right)$ sebesar 0,972 berarti bahwa variabel jumlah pedagang kios $\left(\mathrm{X}_{1}\right)$, jumlah pedagang los $\left(\mathrm{X}_{2}\right)$ dan pertumbuhan ekonomi $\left(\mathrm{X}_{3}\right)$ memberikan sumbangan dalam mempengaruhi penerimaan retribusi pasar $(\mathrm{Y})$ sebesar 97,20 \% sedangkan sisanya sebesar $2,80 \%$ merupakan variabel lain yang tidak diteliti dalam penelitian ini. Nilai $\mathrm{F}$ hitung sebesar 53,663 sedangkan $F$ tabel dengan $\alpha=0,05$ adalah sebesar 6,590 karena nilai $F$ hitung $F$ tabel $(53,663>6,590)$ maka Ho ditolak artinya ada pengaruh dari jumlah pedagang kios $\left(\mathrm{X}_{1}\right)$, jumlah pedagang los $\left(\mathrm{X}_{2}\right)$ danpertumbuhan ekonomi $\left(\mathrm{X}_{3}\right)$ secara bersama-sama terhadap penerimaan retribusi pasar (Y).Nilai $t$ hitung untuk variabel jumlah pedagang kios $\left(\mathrm{X}_{1}\right)$ adalah 5,015; nilai $t$ hitung untuk variabel jumlah pedagang los $\left(\mathrm{X}_{2}\right)$ adalah sebesar 10,357dan nilai $t$ hitung untuk variabel pertumbuhan ekonomi $\left(\mathrm{X}_{3}\right)$ adalah sebesar 4,130sedangkan $t_{\text {tabel }}$ adalah 2,306 karena nilai $\mathrm{t}_{\text {hitung }}>\mathrm{t}_{\text {tabel }}(5,015>2,306 ; 10,357>2,306$ dan $4,130>2,306)$ artinya variabel jumlah pedagang kios $\left(\mathrm{X}_{1}\right)$; jumlah pedagang los $\left(\mathrm{X}_{2}\right)$ dan pertumbuhan ekonomi $\left(\mathrm{X}_{3}\right)$ secara parsial/individu mempunyai pengaruh terhadap penerimaan retribusi pasar $(\mathrm{Y})$.
\end{abstract}

\section{ABSTRACT}

Ellya Revolina, Yuliani; The purpose of this research is to determine the influence of the number of traders stalls, stalls and growing merchant ekonomiterhadap district levies Lebongtahun market in 2004 - 2011 is the data that I use secondary data and sampling methods done by purposive sampling method ie the number of merchant stalls, stalls and growing merchant ekonomiterhadap District levies Lebongtahun market in 2004 - 2011 Based on the calculation results obtained coefficient of Multiple Determination (R2) for 0,972berarti that a variable number of traders stalls (X1), the number of traders los (X $\neg 2)$ and economic growth (X3) contributed in influencing market levies $(Y)$ of $97.20 \%$ while the remaining $2.80 \%$ are other variables not examined in this study. Calculated $F$ value of 53,663 while the $F$ table adengan $=0.05$ is equal to 6.590 as the value of $F$ calculated $>F$ table $(53,663>6.590)$ then Ho is rejected, meaning that there is no influence of the number of traders stalls (X1), the number of traders los $(X \neg 2)$ danpertumbuhan economy (X3) jointly against levies market $(Y)$ the value for a variable number of traders stalls (X1) is 5.015; $t$ value for a variable number of traders los (X2) is equal 10,357dan $t$ value for the economic growth variable (X3) is equal to $2.3064,130$ sedangkan $t$ table is because the value of $t$ count $>t$ table $(5.015>2.306 ; 10.357>2.306$ and $4.130>2.306)$ means that the variable number of traders stalls $(X \neg 1)$; number of traders los (X2) and economic growth (X3) partial / individual has an influence on the market levies ( $Y$ ).

Key words: merchant stalls, traders los, economic growth, market levies

\section{PENDAHULUAN}

Hakekat pembangunan ekonomi adalah serangkaian usaha dan kebijaksanaan yang 
bertujuan untuk meningkatkan taraf hidup masyarakat, memperluas lapangan kerja, meratakan pembagian pendapatan masyarakat, meningkatkan hubungan ekonomi regional dan mengusahakan pergeseran kegiatan ekonomi dari sektor primer ke sektor sekunder dan tersier. Sedangkan arah dari pembangunan ekonomi adalah mengusahakan agar pendapatan masyarakat dapat tercapai secara optimal dan dengan tingkat pemerataan yang sebaik mungkin. Untuk itu pembangunan harus didasarkan pada kekhasan daerah yang bersangkutan dengan menggunakan potensi sumber daya manusia, kelembagaan dan sumber daya fisik yang ada. Oleh sebab itu, pemerintah daerah beserta partisipasi masyarakat harus mampu menaksir potensi sumber daya yang paling diperlukan untuk merancang dan membangun perekonomian daerah.

Pertambahan jumlah penduduk dengan segala aktivitasnya menuntut adanya pemenuhan kebutuhan pelayanan jasa prasarana dan sarana umum, seperti kebutuhan akan pasar. Pasar sebagai sarana umum sangatlah diperlukan untuk memenuhi kebutuhan seharihari. Selain menampung hasil pertumbuhan sektor perdagangan, pasar juga berfungsi menampung hasil-hasil pertanian dan industri rumah tangga dari daerah sekitarnya, sehingga pasar menjadi tempat yang potensial untuk digali sebagai sumber penerimaan pemerintah daerah.

Undang-Undang Nomor 32 Tahun 2004 tentang Pemerintahan Daerah, membawa implikasi yang mendasar terhadap penyelenggaraan pemerintahan di daerah. Pada dasarnya pemberian otonomi daerah adalah dalam rangka membantu penyelenggaraan pemerintah pusat terutama dalam penyediaan pelayanan kepada masyarakat dan pelaksanaan programprogram pembangunan. Pemerintah daerah dipandang sebagai mitra kerja oleh pemerintah pusat dalam penyelenggaraan tugas tersebut. Sehubungan dengan hal tersebut, daerah dituntut untuk lebih aktif dalam upaya meningkatkan kemampuan dan kemandiriannya, menggali serta mengembangkan potensi sumber-sumber ekonomi dalam rangka mempercepat pertumbuhan ekonomi di daerahnya. Pada saat ini titik berat pemberian otonomi daerah diberikan kepada pemerintah daerah provinsi, pemerintah daerah kabupaten dan kota. Untuk merealisasikan pelaksanaan otonomi daerah, maka sumber pembiayaan pemerintah daerah tergantung pada Pendapatan Asli Daerah (PAD).

Upaya meningkatkan kemandirian pembiayaan di daerah perlu dilakukan dengan peningkatan Pendapatan Asli Daerah (PAD), antara lain dengan optimalisasi penggalian dana dari sumber-sumber pendapatan daerah. Retribusi daerah merupakan salah satu bagian dalam pembentukan Pendapatan Asli Daerah (PAD) dan berpotensi untuk dioptimalkan. Prakoso (2005:1) menyebutkan bahwa pajak dan retribusi merupakan salah satu sumber pendapatan yang sangat potensial bagi suatu daerah. Hasil dari pungutan retribusi tersebut selanjutnya akan digunakan untuk kelangsungan kehidupan pemerintah daerah yang bersangkutan, terutama untuk mendanai kegiatan-kegiatan yang berorientasi pada kesejahteraan masyarakat. Undang-Undang Nomor 28 Tahun 2009 tentang Pajak Daerah dan Retribusi Daerah mengatur upaya penyediaan pembiayaan dari sumber tersebut yang antara lain dilakukan dengan peningkatan kinerja pemungutan, penyempurnaan dan penambahan jenis retribusi serta pemberian keleluasaan bagi daerah untuk menggali sumber-sumber penerimaan, khususnya retribusi.

Retribusi daerah sebagai salah satu sumber Pendapatan Asli Daerah (PAD) sekarang ini lebih memungkinkan dan berpeluang besar untuk ditingkatkan dan dikembangkan, sehingga mampu memberikan kontribusi yang yang lebih besar terutama di daerah kabupaten/kota yang mempunyai otonomi yang luas dan utuh sekaligus untuk meningkatkan kualitas pelayanan daerah. Seperti halnya dengan daerah-daerah lain, Kabupaten Lebong sebagai salah satu daerah otonom di Provinsi Bengkulu memiliki potensi yang sangat besar untuk tumbuh dan berkembang. Salah satu jenis retribusi daerah yang ada di Kabupaten Lebong adalah retribusi pasar. Retribusi pasar adalah pungutan atas penyediaan fasilitas pasar tradisional / sederhana, berupa pelataran, los, kios yang dikelola Pemerintah Daerah, dan khusus disediakan untuk pedagang (Undang-UndangNomor 28 Tahun2009).

Penerimaan retribusi pasardapat dipengaruhi oleh banyaknya jumlah pedagang yang ada di dalam pasar tersebut. Hal ini dikarenakan retribusipasar hanya dikenakan kepada para 
pedagang yang berjualan di dalam pasar tersebut, baik pedagang yang berjualan di kios maupun los. Oleh karena itu, jumlah pedagang di pasar secara langsung akan mempengaruhi penerimaan retribusi pasar. Selain itu, pertumbuhan ekonomi suatu daerah juga dapat mempengaruhi penerimaan retribusi pasar, karena pertumbuhan ekonomi yang tinggi akan dapat menciptakan lapangan kerja bagi penduduk di daerah tersebut. Dengan banyaknya lapangan kerja yang ada maka akan banyak penduduk yang bekerja dan memperoleh pendapatan yang akan digunakan untuk memenuhi kebutuhan hidupnya dengan berbelanja di pasar. Dengan demikian para pedagang akan mendapatkan keuntungan, sehingga dapat membayar retribusi pasar.

\section{Landasan Teori KeuanganDaerah}

Di dalam menyelenggarakan otonomi daerah yang luas, nyata dan bertanggungjawab diperlukan keuangan dengan menggali sumber-sumber keuangan sendiri yang didukung pula oleh pembagian keuangan antara pusat dan daerah. Keuangan daerah merupakan salah satu criteria penting untuk mengetahui secara nyata kemampuan daerah dalam mengatur dan mengurus rumah tangganya adalah kemampuan selfsupporting dalam bidang keuangan. Dengan perkataan lain, faktor keuangan merupakan faktor esensial dalam mengukur tingkat kemampuan daerah dalam melaksanakan otonominya. Keadaan keuangan daerahlah yang sangat menentukan corak, bentuk, serta kemungkinan-kemungkinan kegiatan yang akan dilakukan oleh Pemerintah Daerah.

Keuangan daerah sangat penting bagi kestabilan pemerintah daerah, hal ini dikarenakan daerah memiliki beberapa karakteristik (Lains, 1985) sebagai berikut :

1. Sebagian besar pendapatan daerah berasal dari sumbangan atau subsidi serta bantuan dari pemerintah pusat.

2. Kontrol yang meluas dari pemerintah pusat terhadap keuangan pemerintah daerah.

3. Minimnya porsi pendapatan daerah yang dapat dimanfaatkan untuk kepentingan umum.

4. Minimnya kontribusi pajak daerah dan Pendapatan Asli Daerah lainnya terhadap total penerimaan daerah.

Sehubungandenganpentingnya posisikeuanganini,Pamudji(dalam Putranto, 2007 : 10) menegaskan: Pemerintah daerah tidak akan dapat melaksanakan fungsinya dengan efektif dan efisien tanpa biaya yang cukup untuk memberikan pelayanan dan pembangunan. Dan keuangan inilah yang merupakan salah satu dasar criteria untuk mengetahui secara nyata kemampuan daerah dalam mengurus rumah tangganya sendiri. Dari pendapat diatas terlihat bahwa untuk mengatur dan mengurus rumah tangganya, daerah membutuhkan biaya atau uang. Tanpa adanya biaya yang cukup, maka bukan saja tidak mungkin bagi daerah untuk dapat menyelenggarakan tugas kewajiban serta kewenangan yang ada padanya dalam mengatur dan mengurus rumah tangganya, tapi juga ciri pokok dan mendasar dari suatu daerah otonom menjadi hilang.

Dalam Undang-Undang Nomor 33 Tahun 2004 tentang Perimbangan Keuangan antara Pemerintah Pusat dan Pemerintah Daerah dikatakan bahwa sumber penerimaan daerah terdiri atas :

1.PendapatanAsliDaerah(PAD), bersumberdari:

a. Pajak Daerah

Pajak daerah adalah iuran wajib yang dilakukan oleh orang pribadi / badan kepada pemerintah daerah tanpa imbalan langsung yang seimbang dan dapat dipaksakan berdasarkan peraturan perundang-undangan yang berlaku, digunakan untuk membiayai penyelenggaraan pemerintah daerah dan pembangunan daerah.

b. Retribusi Daerah

Retribusi daerah atau retribusi adalah pungutan daerah sebagai pembayaran atas jasa / pemberian izin tertentu yang khusus disediakan atau diberikan oleh pemerintah untuk kepentingan pribadi atau badan.

c. Hasil pengelolaan kekayaan daerah yang dipisahkan 
Laba perusahaan daerah diharapkan sebagai sumber pemasukan bagi daerah. Oleh karena itu, dalam batas-batas tertentu pengelolaan perusahaan haruslah bersifat profesional dan harus tetap berpegang teguh terhadap prinsip ekonomi secara umum dan efisiensi. Perusahaan daerah merupakan salah satu komponen yang diharapkan dapat memberikan kontribusinya bagi pendapatan daerah, akan tetapi bukanlah berorientasi pada keuntungan (profit). Tetapi harus berorientasi pada pemberian pelayanan jasa umum dan manfaat umum. Dengan kata lain, perusahaan daerah menjalankan dua fungsi ganda yang harus terjamin keseimbangannya yaitu fungsi ekonomi (Kaho, 1998 : 169).

d. Lain-lain Pendapatan Asli Daerah (PAD)yangsah.

Penerimaan lain-lain membuka kemungkinan bagi pemerintah daerah untuk melakukan berbagai kegiatan yang menghasilkan, baik berupa materi maupun non materi. Kegiatan tersebut bertujuan untuk menyediakan, melapangkan, memantapkan suatu kebijakan pemerintah daerah dan dapat bertentangan dengan ketentuan peraturan perundangundangan yang berlaku, di lain pihak lebih mengarah kepada public service dan bersifat penyuluhan yaitu tidak mengambil keputusan melainkan hanya sekedar untuk menutup biaya resiko yang dikeluarkan.

2. Dana perimbangan

Dana perimbangan adalah dana yang bersumber dari penerimaan Anggaran Pendapatan dan Belanja Negara (APBN) yang dialokasikan pada daerah untuk mendanai kebutuhan daerah dalam rangka desentralisasi. Dana perimbangan terdiri atas penerimaan pajak bumi dan bangunan, bea perolehan hak atas tanah dan penerimaan dari sumber daya alam dan dana alokasi khusus.

\section{Retribusi}

Munawir (dalam Prakoso, 2005 : 170) menyatakan bahwa retribusi merupakan iuran kepada Pemerintah yang dapat dipaksakan atas jasa balik secara langsung dapat ditunjuk, paksaan di sini bersifat ekonomis karena siapa saja yang tidak merasakan jasa dari Pemerintah tidak dikenakan iuran itu. Sedangkan menurut Henricus (2006 : 197) retribusi adalah pungutan daerah kepada perseorangan atau badan hukum sebagai imbal balik (kontraprestasi) karena yang bersangkutan menikmati jasa atau fasilitas yang disediakan Pemerintah Daerah. Jasa adalah kegiatan Pemerintah berupa usaha dan pelayanan yang menyebabkan barang, fasilitas atau kemanfaatan lainnya, dapat dinikmati oleh orang pribadi atau Badan, artinya bila seseorang ingin menikmati jasa yang disediakan oleh Pemerintah, ia harus membayar retribusi yang ditetapkan sesuai dengan ketentuan yang berlaku. Adapun ciri-ciri retribusi (Kaho, 1998 : 107) adalah :

1. Retribusi dipungut oleh Pemerintah

2. Dalam pemungutan terdapat paksanaan secara ekonomi

3. Adanya kontraprestasi yang secara langsung dapat ditunjuk

4. Retribusi dikenakan pada setiap orang atau badan yang menggunakan/menikmati jasa-jasa yang disiapkan negara.

\section{Retribusi Daerah}

Menurut Mardiasmo (2011 : 15)retribusi daerah adalah pungutan Daerah sebagai pembayaran atas jasa atau pemberian izin tertentu yang khusus disediakan dan/atau diberikan oleh Pemerintah Daerah untuk kepentingan orang pribadi atau Badan.

Adapun yang menjadi objekretribusi daerah (Mardiasmo, 2011 : 16) adalah :

1. Objek retribusi jasa umum adalah pelayanan yang disediakan atau diberikan Pemerintah Daerah untuk tujuan kepentingan dan kemanfaatan umum serta dapat pribadi atau Badan. Jenis retribusijasa umum adalah :

a. Retribusi pelayanan kesehatan;

b. Retribusi pelayanan persampahan/kebersihan;

c. Retribusi penggantian biaya cetak KTP dan Akta Catatan Sipil; 

d. Retribusi pelayanan pemakaman dan pengabuan mayat;
e. Retribusi pelayanan parkir di tepi jalan umum;
f. Retribusi pelayanan pasar;
g. Retribusi pengujian kendaraan bermotor;
h. Retribusi pemeriksaan alat pemadam kebakaran;
i. Retribusi penggantian biaya cetak peta;
j. Retribusi penyediaan dan/atau penyedotan kakus;
k. Retribusi pengolahan limbah cair;
l. Retribusi pelayanan tera/tera ulang;
m.Retribusi pelayanan pendidikan; dan
n. Retribusi pengendalian menara telekomunikasi.

2. Objek retribusi jasa usaha adalah pelayanan yang disediakan oleh Pemerintah Daerah dengan menganut prinsip komersial yang meliputi : (1) pelayanan dengan menggunakan / memanfaatkan kekayaan Daerah yang belum dimanfaatkan secara optimal; dan/atau (2) pelayanan oleh Pemerintah Daerah sepanjang belum disediakan secara memadai oleh pihak swasta.Jenis retribusi jasa usaha adalah :

a. Retribusi pemakaian kekayaan daerah;

b. Retribusi pasar grosir dan/atau pertokoan;

c. Retribusi tempat pelelangan;

d. Retribusi terminal;

e. Retribusi tempat khusus parkir;

f. Retribusi tempat penginapan/pesanggrahan/villa;

g. Retribusi rumah potong hewan;

h. Retribusi pelayanan kepelabuhanan;

i. Retribusi tempat rekreasi dan olahraga;

j. Retribusi penyeberangan di air; dan

k. Retribusi penjualan produksi usaha daerah.

3. Objek retribusi perizinan tertentu adalah pelayanan perizinan tertentu oleh Pemerintah Daerah kepada orang pribadi atau Badan yang dimaksudkanuntuk pengaturan atas kegiatan pemanfaatan ruang, penggunaan sumber daya alam, barang, prasarana, sarana atau fasilitas tertentu guna melindungi kepentingan umum dan menjaga kelestarian lingkungan.Jenis retribusi perizinan tertentu adalah :

a. Retribusi izin mendirikan bangunan;

b. Retribusi izin tempat penjualan minuman beralkohol;

c. Retribusi izin gangguan;

d. Retribusi izin trayek; dan

e. Retribusi izin usaha perikanan.

Sedangkan yang menjadi subjek retribusi daerah (Mardiasmo, 2011 : 18) adalah :

a. Retribusi jasa umum adalah orang pribadi atau Badan yang menggunakan / menikmati pelayanan jasa umum yang bersangkutan.

b. Retribusi jasa usaha adalah orang pribadi atau Badan yang menggunakan / menikmati pelayanan jasa usaha bersangkutan.

c. Retribusi perizinan tertentu adalah orang pribadi atau Badan yang memperoleh izin tertentu dari Pemerintah Daerah.

\section{Pasar}

Pasar adalah area tempat jual beli barang dengan jumlah penjual lebih dari satu, baik yang disebut sebagai pusat perbelanjaan, pasar tradisional, pertokoan, mall, plaza, pusat perdagangan maupun sebutan lainnya. Pasar merupakan suatu mata rantai yang menghubungkan antara produsen dan konsumen. Ajang pertemuan antara penjual dan pembeli, antara dunia usaha dengan masyarakat konsumen. Pasar memainkan peranan yang sangat penting dalam perekonomian modern, karena harga-harga terbentuk di pasar (Putra, 2008 : 51). 
Menurut Puspitasari (2007 : 85) pasar adalah tempat usaha dagang para pedagang eceran kecil yang masing-masing menempati kios dan atau los yang tersedia di pasar itu. Sedangkan menurut Fuad, dkk (2006 : 120) pasar adalah daerah, tempat, wilayah, area yang mengandung kekuatan permintaan dan penawaran yang saling bertemu dan membentuk harga.

Sedangkan dalam Peraturan Menteri Perdagangan RepublikIndonesia Tahun 2008, pasar merupakan area jual beli barang denganpenjual lebih dari satu baik yang disebut sebagai pusat perbelanjaan,pasar tradisional, pertokoan, mall, plaza, pusat perdagangan maupunsebutan lainnya. Pasar ditinjau dari kegiatannya dibedakan menjadipasar tradisional dan pasar modern. Pasar tradisional adalah pasar yangdibangun dan dikelola oleh pemerintah, Pemerintah Daerah dengan tempat usaha berupa toko, kios, los,dan tenda yang dimiliki/dikelola oleh pedagang kecil, menengah,swadaya masyarakat atau koperasi dengan usaha skala kecil, modalkecil dan dengan proses jual beli barang dagangan melalui tawarmenawar.Sedangkan yang dimaksud pasar modern adalah pasar yang dibangun olehpemerintah, swasta, atau koperasi yang dalam bentuknya berupa mall,supermarket, department store, dan shopping centre dimanapengelolaannya dilaksanakan secara modern dan mengutamakanpelayanan kenyamanan berbelanja dengan manajemen berada di satutangan, bermodal relatif kuat, dan dilengkapi tabel harga pasti.

\section{Retribusi Pasar}

Retribusi pasar adalah pungutan atas penyediaan fasilitas pasar tradisional/sederhana berupa pelataran, los, kios yang dikelola Pemerintah Daerah, dan khusus disediakan untuk pedagang (Undang-Undang Nomor 28 Tahun 2009). Sedangkan dalam Peraturan Pemerintah Nomor 66 Tahun 2001, retribusi pasar adalah pungutan atas fasilitas pasar tradisional/sederhana berupa pelataran, los yang dikelola pemerintahan daerah, dan khusus disediakan untuk pedagang, tidak termasuk yang dikelola Badan Usaha Milik Negara, Badan Usaha Milik Daerah dan pihak swasta.

\section{Pedagang}

Pedagang adalah seseorang atau lembaga yang membeli dan menjual barang kembali tanpa mengubah bentuk dan tanggungjawab sendiri dengan tujuan untuk mendapatkan keuntungan (Oktima, 2012 : 224). Menurut Soeharso dan Retnoningsih (2012 : 364) pedagang adalah orang yang berdagang. Sedangkan Firdausa (2012 : 22) mengatakan bahwa pedagang adalah orang yang menjalankan usahaberjualan,usahakerajinan,atauusahapertukangankecil.

Menurut Akhinayasrin (2011) ada jenis-jenis pedagang berdasarkan cara menawarkan barang dagangannya, yaitu :

1. Pedagang keliling, adalah pedagang yang menawarkan barang dagangannya dengan cara berkeliling. Barang yang mereka tawarkan biasanya digendong, dipikul,didorong dengan gerobak, atau diangkut dengan sepeda atau kendaraan bermotor.Termasuk pedagang jenis ini adalah pedagang jamu gendong, pedagang bakso, pedagang es krim dan lain-lain.

2. Pedagang asongan, adalah pedagang yang menawarkan barang dagangannya dengan cara menempatkannya di kotak kecil yang mudah dibawa dan dipindah-pindahkan. Kotak tersebut biasanya mereka kalungkan di leher seperti tas, dan barang-barang yang mereka tawarkan biasanya berupa rokok, korek api, kembang gula, kertas tisu, kacang, kuaci, buah, dan barang-barang ringan lainnya.

3. Pedagang kaki lima, adalah pedagang yang menawarkan barang dagangannya dengan cara menggelarnya di trotoar atau di tepi jalan yang ramai. Untuk menggelar dagangannya, mereka menggunakan tikar, terpal atau semacam balai-balai. Barang-barang yang mereka tawarkan umumnya berupa sepatu, pakaian, makanan, buah-buahan dan lain-lain.

4. Pedagang grosir, adalah adalah pedagang yang dalam menawarkan barang tidak langsung berhadapan dengan calon pembeli. Pedagang grosir tidak langsung menawarkan barang kepada calon pembeli sebagaimana pedagang eceran, melainkan calon pembelilah yang mendatangi pedagang grosir. 


\section{Pertumbuhan Ekonomi}

Pertumbuhan ekonomi merupakan salah satu indikator penting guna menganalisis pembangunan ekonomi yang terjadi di suatu negara. Kuznets (dalam Jhingan, 2010 : 57) mendefinisikan pertumbuhan ekonomi sebagai kenaikan kapasitas dalam jangka panjang dari negara yang bersangkutan untuk menyediakan berbagai barang ekonomi kepada penduduknya. Kemampuan ini tumbuh sesuai dengan kemajuan teknologi, dan penyesuaian kelembagaan dan idiologis yang diperlukannya. Sedangkan Sukirno (2010:9) mengartikan pertumbuhan ekonomi sebagai suatu ukuran kuantitatif yang menggambarkan perkembangan suatu perekonomian dalam suatu tahun tertentu apabila dibandingkan dengan tahun sebelumnya. Perkembangan tersebut selalu dinyatakan dalam bentuk persentase perubahan pendapatan nasional pada suatu tahun tertentu dibandingkan dengan tahun sebelumnya.Sebagai tolak ukur yang paling banyak digunakan untuk mengukur keberhasilan perekonomian suatu daerah adalah Produk Domestik Regional Bruto (PDRB). Menurut BPS (2006 : 16) PDRB adalah jumlah seluruh nilai tambah yang dihasilkan oleh berbagai lapangan usaha atau sektor yang melakukan kegiatan usahanya di suatu daerah tanpa memperhatikan kepemilikan atas faktor produksi. Dengan demikian PDRB dapat dijadikan sebagai pencerminan kemampuan suatu daerah dalam menghasilkan pendapatan atau balas jasa dari faktor-faktor produksi di daerah itu.

Produk Domestik Regional Bruto (PDRB) dapat dihitung dengan dua perhitungan yaitu (1) Penghitungan Atas Dasar Harga Berlaku, merupakan jumlah seluruh nilai tambah bruto atau nilai barang dan jasa akhir yang dihasilkan oleh unit-unit produksi dalam suatu periode tertentu, yang dinilai dengan harga tahun yang bersangkutan; (2) Penghitungan Atas Dasar Harga Konstan, berguna untuk melihat pertumbuhan ekonomi secara kesuluruhan atau sektoral. Juga untuk melihat perubahan struktur perekonomian suatu daerah dari tahun ke tahun.

\section{Faktor-Faktor Yang Mempengaruhi Pertumbuhan Ekonomi}

Menurut Jhingan (2010 : 67) proses pertumbuhan ekonomi dipengaruhi oleh:

1. Faktor Ekonomi

a. Sumber Alam

Faktor utama yang mempengaruhi perkembangan suatu perekonomian adalah sumber alam atau tanah. Tanah dalam ilmu ekonomi mencakup sumber alam seperti kesuburan tanah, letak dan susunannya, kekayaan hutan, mineral, iklim, sumber air, sumber lautan dan sebagainya. Bagi pertumbuhan ekonomi, tersedianya sumber alam secara melimpah merupakan hal yang penting. Suatu negara yang kekurangan sumber alam tidak akan dapat membangun dengan cepat. Tersedianya sumber alam secara melimpah belum cukup bagi pertumbuhan ekonomi, yang terpenting ialah pemanfaatannya secara tepat dengan teknologi yang baik sehingga efisiensi dipertinggi dan sumber dapat dipergunakan dalam jangka waktu lebih lama.

b. Akumulasi Modal

Modal berarti persediaan faktor yang secara fisik dapat direproduksi.Apabila stok modal naik dalam batas waktu tertentu, hal ini disebut akumulasi modal atau pembentukan modal. Proses pembentukan modal bersifat kumulatif dan membiayai diri sendiri serta mencakup tiga tahap : (1) keberadaan tabungan nyata dan kenaikannya; (2) keberadaan lembaga keuangan dan kredit untuk menggalakkan tabungan dan menyalurkannya ke jalur yang dikehendaki; (3) mempergunakan tabungan untuk investasi barang modal.

c. Organisasi

Organisasi berkaitan dengan penggunaan faktor produksi di dalam kegiatan ekonomi. Organisasi bersifat melengkapi (komplemen) modal, buruh dan membantu meningkatkan produktivitasnya. Dalam pertumbuhan ekonomi, para wiraswastawan tampil sebagai organisator dan pengambil risiko di antara ketidakpastian. Wiraswastawan bukanlah manusia dengan kemampuan biasa, ia memiliki kemampuan khusus untuk bekerja dibandingkan orang lain. 
d. Kemajuan Teknologi

Perubahan teknologi dianggap sebagai faktor paling penting dalam proses pertumbuhan ekonomi. Perubahan ini berkaitan dengan perubahan di dalam metode produksi yang merupakan hasil pembaharuan atau penelitian baru. Perubahan pada teknologi telah menaikkan produktivitas buruh, modal dan faktor produksi yang lain. Ada lima pola penting pertumbuhan teknologi di dalam pertumbuhan ekonomi yaitu : penemuan ilmiah atau penyempurnaan pengetahuan teknik; invensi; inovasi; penyempurnaan dan penyebarluasan penemuan yang biasanya diikuti dengan penyempurnaan. Inovasi (pembaharuan) sebagai faktor teknologi yang paling penting dalam pertumbuhan ekonomi. Inovasi terdiri dari dua macam : pertama, penurunan biaya yang tidak menghasilkan perubahan apapun pada kualitas produk; kedua, pembaharuan yang menciptakan produk baru dan menciptakan permintaan baru akan produk tersebut.

e. Pembagian Kerja dan Skala Produksi

Spesialisasi dan pembagian kerja menimbulkan peningkatan produktivitas. Keduanya membawa ke arah ekonomi produksi skala besar yang selanjutnya membantu perkembangan industri. Pembagian kerja menghasilkan perbaikan kemampuan produksi buruh. Setiap buruh menjadi lebih efisien daripada sebelumnya, menghemat waktu, mampu menemukan mesin baru dan berbagai proses baru dalam berproduksi sehingga produksi meningkatkan beberapa hal.

2. Faktor Non Ekonomi

a. Faktor Sosial

Faktor sosial dan budaya juga mempengaruhi pertumbuhan ekonomi. Kekuatan faktor ini menghasilkan perubahan pandangan, harapan, struktur dan nilai-nilai sosial. Orang dibiasakan menabung dan berinvestasi, dan menikmati risiko untuk memperoleh laba. Demi kemajuan ekonomi, perlu adanya perubahan kelembagaan sehingga tabungan dapat digalakkan untuk dikonversi menjadi modal produktif. Untuk itu, lembaga keuangan swasta dan negeri seperti bank tabungan, bursa modal dan saham, bank investasi, bank dagang dan sebagainya harus didirikan.

b. Faktor Manusia

Sumber daya manusia merupakan faktor terpenting dalam pertumbuhan ekonomi. Pertumbuhan ekonomi tidak semata-mata tergantung pada jumlah sumber daya manusia saja, tetapi lebih menekan pada efisiensi mereka. Penggunaan secara tepat sumber daya manusia untuk pembangunan ekonomi dapat dilakukan dengan cara berikut. Pertama, harus ada pengendalian atas perkembangan penduduk. Sumber daya manusia dapat dimanfaatkan dengan baik apabila jumlah penduduk dapat dikendalikan dan diturunkan. Kedua, harus ada perubahan dalam pandangan tenaga buruh. Perilaku sosial dari tenaga buruh merupakan hal yang penting di dalam proses pembangunan ekonomi,

c. Faktor Politik dan Administratif

Faktor politik dan administratif juga membantu pertumbuhan ekonomi modern. Struktur politik dan administrasi yang lemah merupakan penghambat besar bagi pembangunan ekonomi negara terbelakang. Administrasi yang kuat, efisien dan tidak korup, dengan demikian amat penting bagi pembangunan ekonomi. Dalam administrasi yang bersih dan kuat dapat merangsang pertumbuhan ekonomi.

\section{Hipotesis}

Hipotesis adalah perkiraan ilmiah tentang hubungan yang dibangun secara logis antara dua atau lebih variabel, yang diungkapkan dalam bentuk pernyataan yang dapat diuji (Sekaran, 2005 : 235). Dalam penelitian ini dikemukakan hipotesis :Diduga bahwa jumlah pedagang kios, jumlah pedagang los dan pertumbuhan ekonomi berpengaruh terhadap penerimaan retribusi pasar di Kabupaten Lebong tahun 2004 - 2011. 


\section{HASIL DAN PEMBAHASAN \\ Jumlah Penduduk Kabupaten Lebong}

Penduduk berfungsi ganda dalam perekonomian. Di sisi permintaan, penduduk adalah konsumen, sumber permintaan akan barang-barang dan jasa. Di sisi penawaran, penduduk adalah produsen, jika ia pengusaha atau pedagang dan tenaga kerja, jika ia semata-mata pekerja. Untuk melihat jumlah penduduk Kabupaten Lebong tahun 2004 - 2011 dapat dilihat pada Tabel 1. berikut ini.

Tabel 1. Jumlah Penduduk Kabupaten Lebong Tahun 2004 - 2011

\begin{tabular}{|c|c|c|c|}
\hline \multirow{2}{*}{ Tahun Penduduk (jiwa) } & Jumlah & Persentase (\%) \\
\hline 2004 & 90.259 & - & - \\
\hline 2005 & 91.758 & 1.499 & 1,66 \\
\hline 2006 & 93.238 & 1.480 & 1,61 \\
\hline 2007 & 94.590 & 1.352 & 1,45 \\
\hline 2008 & 96.142 & 1.552 & 1,64 \\
\hline 2009 & 97.579 & 1.437 & 1,49 \\
\hline 2010 & 99.215 & 1.636 & 1,68 \\
\hline 2011 & 100.751 & 1.536 & 1,55 \\
\hline
\end{tabular}

Sumber : BPS Kabupaten Lebong, 2012.

Dari Tabel 1. dapat dilihat bahwa penduduk Kabupaten Lebong tahun 2004 - 2011 terus mengalami peningkatan setiap tahunnya. Tahun 2004, penduduk Kabupaten Lebong berjumlah 90.259 jiwa bertambah menjadi 91.758 jiwa (naik 1.499 jiwa atau 1,66 \%) pada tahun 2005. Tahun 2006, penduduk Kabupaten Lebong berjumlah 93.238 jiwa (naik 1.480 jiwa atau 1,61 \%). Tahun 2007, penduduk Kabupaten Lebong berjumlah 94.590 jiwa (naik 1.352 jiwa atau 1,45 \%). Tahun 2008, penduduk Kabupaten Lebong berjumlah 96.142 jiwa (naik 1.552 jiwa atau 1,64 \%). Tahun 2009, penduduk Kabupaten Lebong berjumlah 97.579 jiwa (naik 1.437 jiwa atau 1,49 \%). Tahun 2010, penduduk Kabupaten Lebong berjumlah 99.215 jiwa (naik 1.636 jiwa atau 1,68 \%). Tahun 2011, penduduk Kabupaten Lebong berjumlah 100.751 jiwa (naik 1.536 jiwa atau 1,55 \%). Sedangkan rata-rata peningkatan jumlah penduduk Kabupaten Lebong tahun $2004-2011$ sebanyak 1.312 jiwa atau 1,39\% setiap tahunnya.

\section{Jumlah Pedagang Kios di Pasar Muara Aman dan Pasar Terminal Muara Aman Kabupaten Lebong}

Pedagang kios adalah pedagang yang menempati bangunan kios di pasar. Untuk mengetahui jumlah pedagang kios di Pasar Muara Aman dan Pasar Terminal Muara Aman dapat dilihat pada Tabel 2. di bawah ini.

Tabel 2. Jumlah Pedagang Kios Dipasar Muara Aman Dan Terminal Muara Aman Kabupaten Lebong Tahun $2004-2011$

\begin{tabular}{|c|c|c|c|c|c|}
\hline \multirow[t]{2}{*}{ Tahun } & \multicolumn{2}{|c|}{ Pedagang Kios (buah) } & \multirow[t]{2}{*}{ Total } & \multicolumn{2}{|c|}{ Perkembangan } \\
\hline & Pasar Muara Aman & $\begin{array}{c}\text { Terminal Muara } \\
\text { Aman }\end{array}$ & & Jumlah & $\begin{array}{c}\text { Persentase } \\
(\%)\end{array}$ \\
\hline 2004 & 26 & 41 & 67 & - & - \\
\hline 2005 & 39 & 45 & 84 & 17 & 25,37 \\
\hline 2006 & 42 & 50 & 92 & 8 & 9,52 \\
\hline 2007 & 32 & 48 & 80 & -12 & $-13,04$ \\
\hline 2008 & 51 & 62 & 113 & 33 & 41,25 \\
\hline 2009 & 64 & 87 & 151 & 38 & 33,63 \\
\hline 2010 & 70 & 99 & 169 & 18 & 11,92 \\
\hline 2011 & 82 & 106 & 188 & 19 & 11,24 \\
\hline & & ta-rata & & 15 & 14,99 \\
\hline
\end{tabular}

Sumber : UPTD Pasar Kabupaten Lebong, 2012. 
Dari Tabel 2. dapat dilihat bahwa jumlah pedagang kios di Pasar Muara Aman dan Terminal Muara Aman Kabupaten Lebong tahun 2004 - 2011 cenderung mengalami peningkatan setiap tahunnya. Tahun 2004, jumlah pedagang kios berjumlah 67 orang berubah menjadi 84 orang (bertambah 17 orang atau 25,37\%) pada tahun 2005. Tahun 2006, jumlah pedagang kios berjumlah 92 orang (bertambah 8 orang atau 9,52\%). Tahun 2007, jumlah pedagang kios berjumlah 80 orang (berkurang 12 orang atau 13,04\%). Tahun 2008, jumlah pedagang kios berjumlah 113 orang (bertambah 33 orang atau 41,25\%). Tahun 2009, jumlah pedagang kios berjumlah 151 orang (bertambah 38 orang atau 33,63\%). Tahun 2010, jumlah pedagang kios berjumlah 169 orang (bertambah 18 orang atau 11,92\%). Tahun 2011, jumlah pedagang kios berjumlah 188 orang (bertambah 19 orang atau 11,24\%). Sedangkan rata-rata perkembangan jumlah pedagang kios di Pasar Muara Aman dan Terminal Muara Aman Kabupaten Lebong tahun 2004 - 2011 sebanyak 15 orang atau 14,99\% setiap tahunnya.

\section{Jumlah Pedagang Los di Pasar Muara Aman dan Pasar Terminal Muara Aman Kabupaten Lebong}

Pedagang los adalah pedagang yang menempati tempat berjualan di dalam los. Untuk mengetahui jumlah pedagang los di Pasar Muara Aman dan Pasar Terminal Muara Aman dapat dilihat pada Tabel 3. di bawah ini.

Tabel 3. Jumlah Pedagang Los Dipasar Muara Aman Dan Terminal Muara Aman Kabupaten Lebong Tahun $2004-2011$

\begin{tabular}{|c|c|c|c|c|c|}
\hline \multirow[t]{2}{*}{ Tahun } & \multicolumn{2}{|c|}{ Pedagang Los (buah) } & \multirow[t]{2}{*}{ Total } & \multicolumn{2}{|c|}{ Perkembangan } \\
\hline & Pasar Muara Aman & $\begin{array}{c}\text { Terminal Muara } \\
\text { Aman }\end{array}$ & & Jumlah & $\begin{array}{c}\text { Persentase } \\
(\%)\end{array}$ \\
\hline 2004 & 31 & 23 & 54 & - & - \\
\hline 2005 & 34 & 26 & 60 & 6 & 11,11 \\
\hline 2006 & 38 & 29 & 67 & 7 & 11,67 \\
\hline 2007 & 36 & 28 & 64 & -3 & $-4,48$ \\
\hline 2008 & 47 & 36 & 83 & 19 & 29,69 \\
\hline 2009 & 66 & 51 & 117 & 34 & 40,96 \\
\hline 2010 & 76 & 58 & 134 & 17 & 14,53 \\
\hline 2011 & 82 & 62 & 144 & 10 & 7,46 \\
\hline & & ta-rata & & 11 & 13,87 \\
\hline
\end{tabular}

Sumber : UPTD Pasar Kabupaten Lebong, 2012.

Dari Tabel 3. dapat dilihat bahwa jumlah pedagang los di Pasar Muara Aman dan Terminal Muara Aman Kabupaten Lebong tahun 2004 - 2011 cenderung mengalami peningkatan setiap tahunnya. Tahun 2004, jumlah pedagang los berjumlah 54 orang berubah menjadi 60 orang (bertambah 6 orang atau 11,11\%) pada tahun 2005. Tahun 2006, jumlah pedagang los berjumlah 67 orang (bertambah 7 orang atau 11,67\%). Tahun 2007, jumlah pedagang los berjumlah 64 orang (berkurang 3 orang atau 4,48\%). Tahun 2008, jumlah pedagang los berjumlah 83 orang (bertambah 19 orang atau 29,69\%). Tahun 2009, jumlah pedagang los berjumlah 117 orang (bertambah 34 orang atau 40,96\%). Tahun 2010, jumlah pedagang los berjumlah 134 orang (bertambah 17 orang atau 14,53\%). Tahun 2011, jumlah pedagang los berjumlah 144 orang (bertambah 10 orang atau 7,46 \%). Sedangkan rata-rata perkembangan jumlah pedagang los di Pasar Muara Aman dan Terminal Muara Aman Kabupaten Lebong tahun 2004 - 2011 sebanyak 11 orang atau 13,87 \% setiap tahunnya.

\section{Produk Domestik Regional Bruto Kabupaten Lebong}

PDRB merupakan salah satu indikator yang dipakai untuk mengukur tingkat kemajuan pembangunan suatu daerah atau wilayah. Untuk mengetahui PDRB Kabupaten Lebongkonstan tahun 2004 - 2011 dapat dilihat pada Tabel 4. di bawah ini. 
Tabel 4. Produk Domestikregional Bruto Atas Dasar Harga Konstan Kabupaten Lebong Tahun $2004-2011$.

\begin{tabular}{|c|c|c|c|}
\hline \multirow[t]{2}{*}{ Tahun } & \multirow{2}{*}{$\begin{array}{l}\text { Produk Domestik Regional Bruto } \\
\text { (Rp. juta ) }\end{array}$} & \multicolumn{2}{|c|}{ Peningkatan } \\
\hline & & Jumlah & Persentase (\%) \\
\hline 2004 & 381.893 & - & - \\
\hline 2005 & 402.784 & 20.891 & 5,47 \\
\hline 2006 & 424.260 & 21.476 & 5,33 \\
\hline 2007 & 445.941 & 21.681 & 5,11 \\
\hline 2008 & 468.201 & 22.260 & 4,99 \\
\hline 2009 & 490.137 & 21.936 & 4,69 \\
\hline 2010 & 515.045 & 24.908 & 5,08 \\
\hline 2011 & 544.474 & 29.429 & 5,71 \\
\hline & Rata-rata & 20.323 & 4,55 \\
\hline
\end{tabular}

Sumber : BPS Kabupaten Lebong, 2012.

Dari Tabel IV dapat dilihat bahwa PDRB Kabupaten Lebong atas dasar harga konstan tahun 2004 - 2011 mengalami peningkatan dari tahun ke tahun. Dimana PDRB Kabupaten Lebong pada tahun 2004 sebesar Rp. 381.893 juta berubah menjadi Rp. 402.784juta (naik Rp. 20.891 juta atau 5,47 \%) pada tahun 2005. Tahun 2006, PDRB Kabupaten Lebong sebesar Rp. 424.260 juta (naik Rp. 21.476 juta atau 5,33 \%). Tahun 2007, PDRB Kabupaten Lebong sebesar Rp. 445.941 juta (naik Rp. 21.681 juta atau 5,11 \%). Tahun 2008, PDRB Kabupaten Lebong sebesar Rp. 468.201 juta (naik Rp. 22.260 juta atau 4,99 \%). Tahun 2009, PDRB Kabupaten Lebong sebesar Rp. 490.137 juta (naik Rp. 21.936 juta atau 4,69 \%). Tahun 2010, PDRB Kabupaten Lebong sebesar Rp. 515.045 juta (naik Rp. 24.908 juta atau 5,08 \%).Tahun 2011, PDRB Kabupaten Lebong sebesar Rp. 544.474 juta (naik Rp. 29.429 juta atau 5,71 \%).Sedangkan rata-rata peningkatan PDRBKabupaten Lebong tahun 2004 - 2011 sebesar Rp. 20.323 juta atau $4,55 \%$ setiap tahunnya.

\section{Pertumbuhan Ekonomi Kabupaten Lebong}

Pertumbuhan ekonomi merupakan salah satu tolak ukur dalam menilai kebijakan pembangunan yang dilakukan khususnya di bidang ekonomi. Untuk melihat pertumbuhan ekonomi dari tahun ke tahun dapat dilihat dari perkembangan Produk Domestik Regional Bruto (PDRB).Untuk mengetahui pertumbuhan ekonomi Kabupaten Lebongtahun 2004 - 2011 dapat dilihat pada Tabel 5. berikut ini.

Tabel 5. Pertumbuhan Ekonomi Kabupaten Lebong Tahun 2004 - 2011

\begin{tabular}{|c|c|c|}
\hline Tahun & Pertumbuhan Ekonomi ( \% ) & Perkembangan \\
\hline 2004 & 5,35 & - \\
\hline 2005 & 5,47 & 0,12 \\
\hline 2006 & 5,33 & $-0,14$ \\
\hline 2007 & 5,11 & $-0,22$ \\
\hline 2008 & 4,99 & $-0,12$ \\
\hline 2009 & 4,69 & $-0,30$ \\
\hline 2010 & 5,08 & 0,39 \\
\hline 2011 & 5,71 & 0,63 \\
\hline \multicolumn{2}{|r|}{ Rata-rata } & 0,05 \\
\hline
\end{tabular}

Sumber : BPS Kabupaten Lebong, 2012.

Dari Tabel 5. dapat dilihat bahwa pertumbuhan ekonomi Kabupaten Lebongtahun 2004 - 2011cenderung mengalami penurunan dari tahun ke tahun. Tahun 2004, pertumbuhan ekonomi Kabupaten Lebong sebesar 5,35 \% berubah menjadi 5,47 \% (naik 0,12\%) pada tahun 2005. Tahun 2006, pertumbuhan ekonomi Kabupaten Lebong sebesar 5,33\% (turun 0,14 \%). Tahun 2007, pertumbuhan ekonomi Kabupaten Lebong sebesar 5,11 \% (turun 0,22 \%). Tahun 
2008, pertumbuhan ekonomi Kabupaten Lebong sebesar 4,99 \% (turun 0,12 \%). Tahun 2009, pertumbuhan ekonomi Kabupaten Lebong sebesar 4,69 \% (turun 0,30 \%). Tahun 2010, pertumbuhan ekonomi Kabupaten Lebong sebesar 5,08 \% (naik 0,39 \%). Tahun 2011, pertumbuhan ekonomi Kabupaten Lebong sebesar 5,71 \% (naik 0,63 \%). Sedangkan rata-rata peningkatan pertumbuhan ekonomiKabupaten Lebong tahun $2004-2011$ sebesar 0,05\% setiap tahunnya.

\section{Penerimaan Retribusi Pasar di Kabupaten Lebong}

Retribusi pasar adalah pungutan atas penyediaan fasilitas pasar tradisional/sederhana berupa pelataran, los, kios yang dikelola Pemerintah Daerah, dan khusus disediakan untuk pedagang. Untuk mengetahui penerimaan retribusi pasar di Kabupaten Lebong tahun 2004 2011 dapat dilihat pada Tabel 6. di bawah ini.

Tabel 6. Penerimaan Retribusi Pasar Di Kabupaten Lebong Tahun 2004 - 2011.

\begin{tabular}{|c|c|c|c|}
\multirow{2}{*}{ Tahun } & Penerimaan Retribusi Pasar (rupiah) & \multicolumn{2}{c|}{ Peningkatan } \\
\cline { 3 - 4 } & 13.251 .000 & - & Jumlah \\
\hline 2004 & 14.674 .000 & 1.423 .000 & 10,74 \\
\hline 2005 & 16.449 .000 & 1.775 .000 & 12,10 \\
\hline 2006 & 15.947 .000 & -502.000 & $-3,05$ \\
\hline 2007 & 20.891 .000 & 4.944 .000 & 31,00 \\
\hline 2008 & 29.531 .000 & 8.640 .000 & 41,36 \\
\hline 2009 & 33.693 .000 & 4.162 .000 & 14,09 \\
\hline 2010 & 36.615 .000 & 2.922 .000 & 8,67 \\
\hline 2011 & Rata-rata & $\mathbf{2 . 9 2 0 . 5 0 0}$ & $\mathbf{1 4 , 3 6}$ \\
\hline
\end{tabular}

Sumber : DPPKAD Kabupaten Lebong, 2012.

Dari Tabel 6. dapat dilihat bahwa penerimaan retribusi pasar di Kabupaten Lebong tahun 2004 - 2011 cenderung mengalami peningkatan setiap tahunnya. Tahun 2004, penerimaan retribusi pasar sebesar Rp. 13.251 .000 berubah menjadi Rp. 14.674 .000 (bertambah Rp. 1.423 .000 atau $10,74 \%$ ) pada tahun 2005. Tahun 2006, penerimaan retribusi pasar sebesar Rp. 16.449.000 (bertambah Rp. 1.775 .000 atau 12,10 \%).Tahun 2007, penerimaan retribusi pasar sebesar Rp. 15.947.000 (berkurangRp. 502.000 atau 3,05 \%).Tahun 2008, penerimaan retribusi pasar sebesar Rp. 20.891.000 (bertambah Rp. 4.944.000 atau 31,00 \%).Tahun 2009, penerimaan retribusi pasar sebesarRp. 29.531.000 (bertambah Rp. 8.640.000 atau 41,36 \%).Tahun 2010, penerimaan retribusi pasar sebesar Rp. 33.693.000 (bertambah Rp. 4.162.000 atau 14,09 \%).Tahun 2011, penerimaan retribusi pasar sebesar Rp. 36.615 .000 (bertambah Rp. 2.922.000 atau 8,67 \%). Sedangkan rata-rata perkembangan penerimaan retribusi pasar di Kabupaten Lebong tahun 2004 - 2011 sebesar Rp. 2.920 .500 atau 14,36 \% setiap tahunnya.

\section{Pembahasan} berikut :

Berdasarkan hasil perhitungan yang dilakukan, maka dilakukan pembahasan sebagai

1. Analisis Regresi Linier Berganda

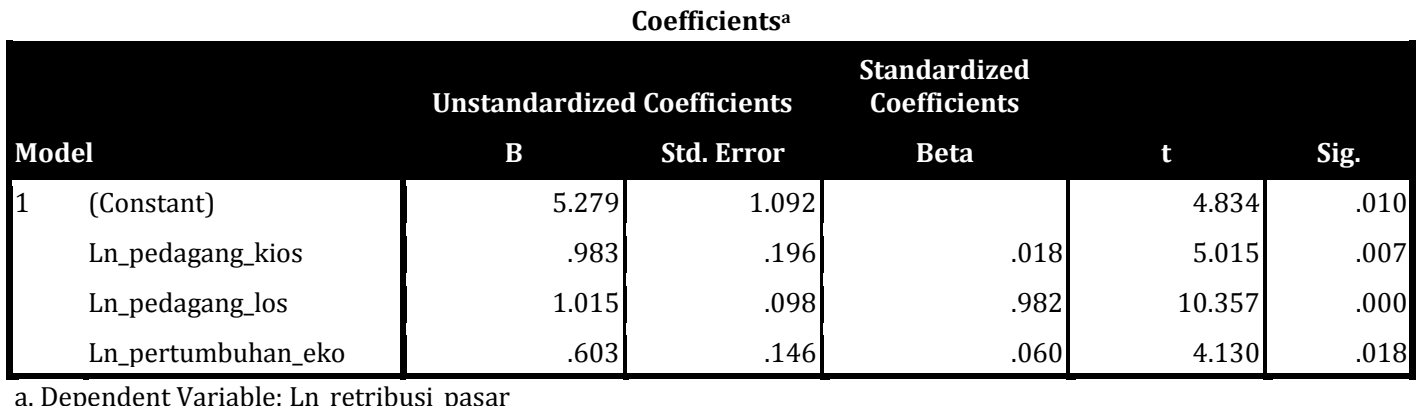


Dari perhitungan yang dilakukan dengan Program SPSS, diperoleh persamaan Regresi Linier Berganda sebagai berikut :

\section{$\operatorname{Ln} Y=5,279+0,983 \operatorname{Ln} X_{1}+1,015 \operatorname{Ln} X_{2}+0,603 \operatorname{Ln} X_{3}$}

Arti dari persamaan Regresi Linier Berganda tersebut adalah :

- Nilai konstanta = 5,279 mempunyai arti bahwa jumlah pedagang kios $\left(\mathrm{X}_{1}\right)$, jumlah pedagang los $\left(\mathrm{X}_{2}\right)$ danpertumbuhan ekonomi $\left(\mathrm{X}_{3}\right)$ dianggap tetap (cateris paribus), maka penerimaan retribusi pasar (Y) akan naik sebesar 5,279.

- Koefisien variabel jumlah pedagang kios $\left(X_{1}\right)=0,983$ mempunyai arti apabila jumlah pedagang kios $\left(\mathrm{X}_{1}\right)$ ditingkatkan dalam satu satuan maka penerimaan retribusi pasar $(\mathrm{Y})$ akan naik sebesar 0,983 dengan asumsi variabel jumlah pedagang los $\left(\mathrm{X}_{2}\right)$ dan pertumbuhan ekonomi $\left(\mathrm{X}_{3}\right)$ tetap.

- Koefisien variabel jumlah pedagang los $\left(\mathrm{X}_{2}\right)=1,015$ mempunyai arti bahwa apabila jumlah pedagang los $\left(\mathrm{X}_{2}\right)$ ditingkatkan dalam satu satuan maka penerimaan retribusi pasar $(\mathrm{Y})$ akan naik sebesar 1,015 dengan asumsi variabel jumlah pedagang kios $\left(\mathrm{X}_{1}\right)$ danpertumbuhan ekonomi $\left(\mathrm{X}_{3}\right)$ tetap.

- Koefisien variabel pertumbuhan ekonomi $\left(\mathrm{X}_{3}\right)=0,603$ mempunyai arti bahwa apabila pertumbuhan ekonomi $\left(\mathrm{X}_{3}\right)$ ditingkatkan dalam satu satuan maka penerimaan retribusi pasar $(\mathrm{Y})$ akan meningkat sebesar 0,603 dengan asumsi variabel jumlah pedagang kios $\left(\mathrm{X}_{1}\right)$ danjumlah pedagang los $\left(\mathrm{X}_{2}\right)$ tetap.

2. Koefisien Determinasi $\left(\mathrm{R}^{2}\right)$

\begin{tabular}{|c|c|c|c|c|}
\hline \multicolumn{5}{|c|}{ Model Summary } \\
\hline Model & $\mathbf{R}$ & R Square & Adjusted R Square & Std. Error of the Estimate \\
\hline 1 & $.986^{a}$ & .972 & .950 & .07579 \\
\hline
\end{tabular}

Dari hasil perhitungan diperoleh Koefisien Determinasi $\left(R^{2}\right)=0,972$ hal ini berarti bahwa variabel jumlah pedagang kios $\left(X_{1}\right)$, jumlah pedagang los $\left(X_{2}\right)$ dan pertumbuhan ekonomi $\left(X_{3}\right)$ memberikan sumbangan dalam mempengaruhi penerimaan retribusi pasar (Y) sebesar 97,20\% sedangkan sisanya sebesar 2,80 \% merupakan sumbangan variabel lain yang tidak diteliti dalam penelitian ini. Sedangkan Koefisien Korelasi Linier Berganda (R) $=0,986$ hal ini berarti terdapat korelasi yang kuat antara variabel jumlah pedagang kios $\left(\mathrm{X}_{1}\right)$, jumlah pedagang los $\left(\mathrm{X}_{2}\right)$ danpertumbuhan ekonomi $\left(\mathrm{X}_{3}\right)$ dengan penerimaan retribusi pasar $(\mathrm{Y})$.

3. Pengujian Hipotesis

a. Uji F

ANOVA $^{\mathrm{b}}$

\begin{tabular}{|c|c|c|c|c|c|c|}
\hline & Model & Sum of Squares & $\mathrm{df}$ & Mean Square & $\mathrm{F}$ & Sig. \\
\hline 1 & Regression & 6.026 & 3 & 2.009 & 53.663 & $.000^{\mathrm{a}}$ \\
\hline & Residual & 1.373 & 4 & .343 & & \\
\hline & Total & 7.399 & 7 & & & \\
\hline
\end{tabular}

a. Predictors: (Constant), Ln_pertumbuhan_eko, Ln_pedagang_kios, Ln_pedagang_los

b. Dependent Variable: Ln_retribusi_pasar

Untuk uji hipotesis secara bersama-sama digunakan alat analisis Uji - F , dari hasil perhitungan diperoleh nilai $\mathrm{F}_{\text {hitung }}$ sebesar 53,663 sedangkan $\mathrm{F}_{\text {tabel }}$ dengan $\alpha=0,05$ adalah sebesar 6,590 karena nilai $F$ hitung $>F$ tabel $(53,663>6,590)$ maka Ho ditolak artinya ada pengaruh dari jumlah pedagang kios $\left(\mathrm{X}_{1}\right)$, jumlah pedagang los $\left(\mathrm{X}_{2}\right)$ danpertumbuhan ekonomi $\left(\mathrm{X}_{3}\right)$ secara bersama-sama terhadap penerimaan retribusi pasar $(\mathrm{Y})$. 
b. $\mathrm{Uji}-\mathrm{t}$

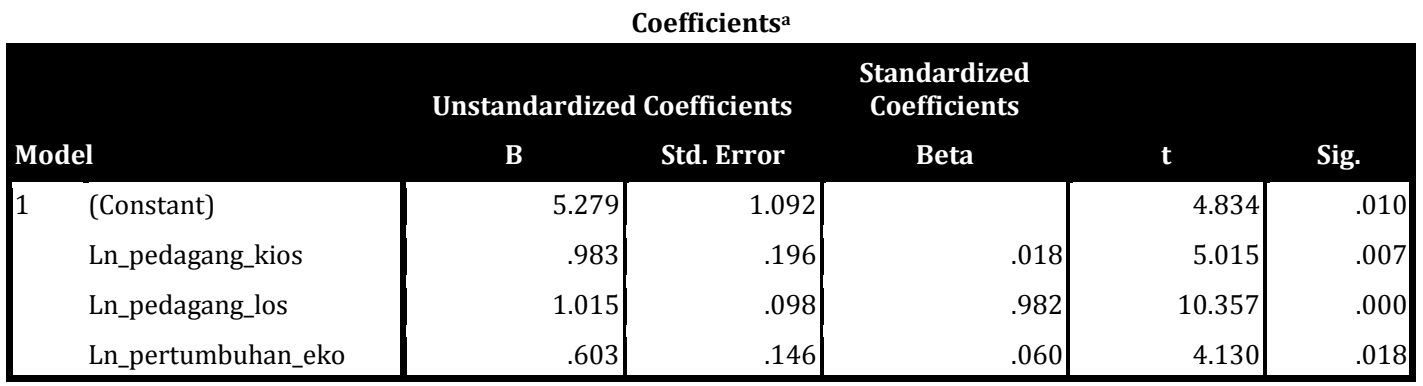

a. Dependent Variable: Ln_retribusi_pasar

Untuk uji hipotesis secara parsial/individu digunakan alat analisis Uji - t , dari hasil perhitungan diperoleh :

- Nilai $\mathrm{t}_{\text {hitung }}$ untuk variabel jumlah pedagang kios $\left(\mathrm{X}_{1}\right)$ adalah sebesar 5,015 sedangkan $\mathrm{t}$ tabel dengan $\alpha=0,05 / 2$ adalah sebesar 2,306 karena nilai $t$ hitung $>t$ tabel $(5,015>2,306)$ maka Ho ditolak, artinya variabel jumlah pedagang kios $\left(\mathrm{X}_{1}\right)$ mempunyai pengaruh terhadap penerimaan retribusi pasar (Y).

- Nilai $t$ hitung untuk variabel jumlah pedagang los $\left(X_{2}\right)$ adalah sebesar 10,357 sedangkan $t$ tabel dengan $\alpha=0,05 / 2$ adalah sebesar 2,306 karena nilai $t$ hitung $>t$ tabel $(10,357>2,306)$ maka Ho ditolak, artinya variabel jumlah pedagang $\operatorname{los}\left(\mathrm{X}_{2}\right)$ mempunyai pengaruh terhadap penerimaan retribusi pasar (Y).

- Nilai $t_{\text {hitung }}$ untuk variabel pertumbuhan ekonomi $\left(X_{3}\right)$ adalah sebesar 4,130 sedangkan $t$ tabel dengan $\alpha=0,05 / 2$ adalah sebesar 2,306 karena nilai $t_{\text {hitung }}>t$ tabel $(4,130>2,306)$ maka Ho ditolak, artinya variabel pertumbuhan ekonomi $\left(\mathrm{X}_{3}\right)$ mempunyai pengaruh terhadap penerimaan retribusi pasar (Y).

\section{Kesimpulan}

1. Faktor yang mempengaruhi penerimaan retribusi pasar di Kabupaten Lebong tahun 2004 2011 adalah jumlah pedagang kios, jumlah pedagang los dan pertumbuhan ekonomi, di mana jumlah pedagang los mempunyai pengaruh yang lebih kuat dalam mempengaruhi penerimaan retribusi pasar di Kabupaten Lebong dibandingkan dengan pedagang kios dan pertumbuhan ekonomi. Hal ini dapat dilihat dari tingkat signifikan jumlah pedagang los sebesar 0,000 lebih besar dibandingkan tingkat signifikan jumlah pedagang kios sebesar 0,007 dan tingkat signifikan pertumbuhan ekonomi sebesar 0, 018 .

2. Dari perhitungan diperoleh persamaan Regresi Linier Berganda sebagai berikut :

\section{$\operatorname{Ln} Y=5,279+0,983 \operatorname{Ln} X_{1}+1,015 \operatorname{Ln} X_{2}+0,603 \operatorname{Ln} X_{3}$}

Nilai konstanta $=5,279$ artinyaapabilajumlah pedagang kios $\left(\mathrm{X}_{1}\right)$, jumlah pedagang los $\left(\mathrm{X}_{2}\right)$ danpertumbuhan ekonomi $\left(\mathrm{X}_{3}\right)$ dianggap tetap (cateris paribus), maka penerimaan retribusi pasar $(Y)$ akan naik sebesar 5,279. Koefisien variabel jumlah pedagang kios $\left(\mathrm{X}_{1}\right)=$ 0,983 artinya apabila jumlah pedagang kios $\left(\mathrm{X}_{1}\right)$ ditingkatkan dalam satu satuan maka penerimaan retribusi pasar $(\mathrm{Y})$ akan naik sebesar 0,983. Koefisien variabel jumlah pedagang los $\left(\mathrm{X}_{2}\right)=1,015$ artinya apabila jumlah pedagang los $\left(\mathrm{X}_{2}\right)$ ditingkatkan dalam satu satuan maka penerimaan retribusi pasar (Y) akan naik sebesar 1,015.Koefisien variabel pertumbuhan ekonomi $\left(\mathrm{X}_{3}\right)=0,603$ artinya apabila pertumbuhan ekonomi $\left(\mathrm{X}_{3}\right)$ ditingkatkan dalam satu satuan maka penerimaan retribusi pasar (Y) akan meningkat sebesar 0,603.

3. Koefisien Korelasi Linier Berganda $(R)=0,986$ artinya terdapat korelasi yang kuat antara variabel jumlah pedagang kios $\left(\mathrm{X}_{1}\right)$, jumlah pedagang los $\left(\mathrm{X}_{2}\right)$ danpertumbuhan ekonomi $\left(\mathrm{X}_{3}\right)$ dengan penerimaan retribusi pasar $(\mathrm{Y})$.

3. Koefisien Determinasi $\left(\mathrm{R}^{2}\right)=0,972$ artinya variabel jumlah pedagang kios $\left(\mathrm{X}_{1}\right)$, jumlah pedagang los $\left(\mathrm{X}_{2}\right)$ dan pertumbuhan ekonomi $\left(\mathrm{X}_{3}\right)$ memberikan sumbangan dalam mempengaruhi penerimaan retribusi pasar (Y) sebesar 97,20 \% sedangkan sisanya sebesar $2,80 \%$ merupakan sumbangan variabel lain. 
4. Nilai $F_{\text {hitung }}$ sebesar $53,663>$ nilai $F_{\text {tabel }}$ sebesar 6,590 maka Ho ditolak artinya ada pengaruh dari jumlah pedagang kios $\left(\mathrm{X}_{1}\right)$, jumlah pedagang los $\left(\mathrm{X}_{2}\right)$ danpertumbuhan ekonomi $\left(\mathrm{X}_{3}\right)$ secara bersama-sama terhadap penerimaan retribusi pasar $(\mathrm{Y})$.

5. Nilai $t$ hitung untuk variabel jumlah pedagang kios $\left(X_{1}\right)$ adalah 5,015; untuk variabel jumlah pedagang los $\left(\mathrm{X}_{2}\right)$ adalah 10,357dan untuk variabel pertumbuhan ekonomi $\left(\mathrm{X}_{3}\right)$ adalah 4,130 sedangkan $t_{\text {tabel }}$ adalah 2,306 karena nilai $t_{\text {hitung }}>t_{\text {tabel }}(5,015>2,306 ; 10,357>2,306$ dan $4,130>2,306)$ artinya variabel jumlah pedagang kios $\left(\mathrm{X}_{1}\right)$; jumlah pedagang los $\left(\mathrm{X}_{2}\right)$ dan pertumbuhan ekonomi $\left(\mathrm{X}_{3}\right)$ secara parsial/individu mempunyai pengaruh terhadap penerimaan retribusi pasar $(\mathrm{Y})$.

\section{Saran}

1. Pemerintah Daerah Kabupaten Lebong melalui Dinas Koperasi, UKM dan Perindag; khususnya melalui UPTD Pasar agar dapat lebih mengoptimalkan lagi penarikan retribusi pasar terhadap pedagang kios dan pedagang los.

2. Pemerintah Daerah Kabupaten Lebong agar dapat meningkatkan pertumbuhan ekonomi pasar, melalui penataan yang lebih baik agar kegiatan perekonomian di dalam pasar lebih meningkat sehingga akan menarik pedagang untuk membuka usaha dalam kios atau los di area pasar.

\section{DAFTAR PUSTAKA}

Anonim, 2001. Peraturan Pemerintah Nomor 66 Tahun 2001 Tentang Retribusi Daerah. Jakarta.

-------, 2004. UU Nomor 32 Tahun 2004 TentangPemerintahan Daerah.Jakarta.

------, 2009. UU Nomor 28 Tahun 2009 Tentang Pajak dan Retribusi Daerah. Jakarta.

Firdausa, Rosetyadi, Artistyan. 2012. Pengaruh Modal Awal, Lama Usaha dan Jam Kerja Terhadap Pendapatan Pedagang Kios di Pasar Bintono Demak. Skripsi. Universitas Diponegoro.

Fuad, M, dkk. 2006. Pengantar Bisnis. Jakarta. Gramedia.

Jhingan, M.L. 2010. Ekonomi Pembangunan dan Perencanaan. Jakarta. Raja Grafindo.

Kaho, Riwu, Josep. 1998. Prospek Otonomi Daerah di Indonesia. Jakarta. Raja Grafindo.

Mardiasmo. 2011. Perpajakan. Yogyakarta. Andi.

Oktima, Nurul. 2012. Kamus Ekonomi. Surakarta. Aksara Sinergi Media.

Prakoso,Bambang,Kesit.2005.PajakdanRetribusiDaerah.Yogyakarta.UIIPress.

Putranto. 2007. Retribusi Pelayanan Pasar Banget Ayu dan Peterongan Kota Semarang. Skripsi. Universitas Negeri Semarang.

Putra, Windhu. 2008. Ekonomi Industri. Bandung. Alfabeta.

Raga, Wisnu, Arjanggi. 2011. Analisis Kinerja Penerimaan Retribusi Pasar di Kabupaten Demak Tahun 2006 - 2009. Skripsi. Universitas Diponegoro.

Riduwan dan Sunarto. 2010. Pengantar Statistika : Untuk Penelitian Pendidikan, Sosial, Ekonomi, Komunikasi dan Bisnis. Bandung. Alfabeta. 
Sekaran, Uma. 2005. Metodelogi Penelitian Untuk Bisnis. Jakarta. Salemba Empat

Singarimbun, Masri dan Effendi, Sofyan. 2006. Metode Penelitian Survey. Yogyakarta. LP3ES

Soeharso dan Retnoningsih, Ana. 2012. Kamus Besar Bahasa Indonesia. Semarang. Widya Karya

Sujarweni, Wiratna, V dan Endrayanto, Poly. 2012. Statistika Untuk Penelitian. Yogyakarta. Graha Ilmu.

Sukirno, Sadono. 2010. Ekonomi Pembangunan; Proses, Masalah Dan DasarKebijaksanaan. Jakarta. LPFE-UI. 